\title{
Emotional Intelligence, Subjective Wellbeing, and Work-Family Conflict Among University Lecturers
}

\author{
Amalia Juniarly, Ayu Purnamasari, Dewi Anggraini, and Heni Andini \\ Psychology Study Program, Faculty of Medicine \\ University of Sriwijaya
}

\begin{abstract}
The purpose of this study is to determine the role of emotional intelligence and subjective wellbeing in predicting work-family conflict. The participants for the study were 182 female lecturers at University of Sriwijaya, and the pilot study of the measuring scales was conducted with 52 lecturers. The scales used were the scales of emotional intelligence, subjective wellbeing and work-family conflict. Data analysis employed multiple linear regression. The results of the analysis were that there is a significant role for emotional wellbeing and subjective wellbeing concerning work-family conflict.
\end{abstract}

Keywords: emotional intelligence, subjective wellbeing, work-family conflict

Tujuan penelitian untuk mengetahui peran kecerdasan emosi dan kesejahteraan subjektif dalam memprediksikan konflik peran ganda (kerja-keluarga). Partisipan penelitian ini adalah 182 perempuan dosen Universitas Sriwijaya, dan uji coba alat ukur dilakukan pada 52 orang. Alat ukur yang digunakan adalah skala kecerdasan emosi, kesejahteraan subjektif dan konflik peran ganda. Analisis data menggunakan regresi linear berganda. Hasil analisis menunjukkan ada peran signifikan kecerdasan emosi dan kesejahteraan subjektif terhadap konflik peran ganda.

Kata kunci: kecerdasan emosi, kesejahteraan subjektif, konflik peran ganda

Traditionally, the role of a married woman was as a stay-at-home mother and a wife. Recent demographic and technological changes have altered this traditional role. A woman is no longer regarded as someone who does the housework, but as someone having the same role as a man, who can work in various fields according to her competence. The Workforce Participation Rate data in 2014 showed that the number of working women is $50.22 \%$ of the workforce, which is greater than the previous, when it was only about $38.79 \%$ (Rahayu, 2015). This increase indicates the number of women working is now more than the number of men. One of the reasons behind women's decisions to work is their increased education levels, so they would find it a shame if they did not actualize themselves by working. Another reason is their husband's income levels are not sufficient to fulfill family needs, when the size of the family is quite large. This has driven some women to decide to work, in jobs such as becoming lecturers.

Correspondence concerning this article should be addressed to Amalia Juniarly, Psychology Study Program, Faculty of Medicine, Sriwijaya University Jalan Raya Palembang-Prabumulih Km 32 Inderalaya, Palembang 30662. E-mail: amaliajuniarly@ fk.unsri.ac.id
Republic of Indonesia Law No. 14 of 2005 on Teachers and Lecturers (Undang-Undang Republik Indonesia, 2017) explains that lecturers are professional educators and scientists, with the primary tasks of transforming, developing and disseminating science, technology and the arts, through education and community service. As professionals, lecturers need skills and expertise which are of a certain quality or meet certain standards which may well require further professional education. The main task of lecturers is to implement what is known as Tridharma (The Three Main Pillars of Higher Education) with a workload of at least 12 and at most 16 credits, in accordance with his/her academic classification. The implementation of Tridharma is the main duty of a lecturer, and consists of three main functions, namely, provision of education and teaching, research and development, and community service. In addition to teaching, lecturers are also required to supervise theses, and to conduct research and community service. Owing to this high workload, sometimes unfinished tasks are brought home. They work hard in performing Tridharma and striving to advance their university careers. Consequently, such conditions create more 
pressure and conflict for them than for regular female employees, who can complete their work at the office and do not need to bring their work home.

The burden of work brought home can affect an individual's physical and psychological condition, especially for lecturers who are married and have children. Frone (as cited in Baah, 2015) states that married female employees with children have more roles and responsibilities than single women. In addition to work responsibilities, married women are often expected still to be responsible for taking care their husbands and children.

These overlapping roles may lead to conflicts in their roles as housewives, or cause problems at work. The conflict experienced by working women is known as work-family conflict. According to Posig and Kickul (as cited in Erkmen \& Esen, 2014), work-family conflict is a form of conflict between work and family, in which roles are contradictory, in some respects. Greenhaus and Beutell as well as Jimenez et al. (as cited in Sianturi \& Zulkarnain, 2013) explain in more detail that this conflict occurs because the demands of roles originating in one domain (workplace or family) do not match the demands of roles in other domains. As Noor (2004) notes, work-family conflict is divided into two parts. The first is Work Interfering with Family (WIF), which occurs when workrelated activities interfere with home responsibilities, for example, employees bringing home tasks, the completion of which is conducted at the expense of family time. The second is Family Interfering with Work (FIW), which occurs when the responsibility for family roles inhibits work activities. An example of this is someone who has to cancel an important appointment, because a child is suddenly sick. Stoner, Hartman, and Arora (as cited in Baah, 2015) define work-family conflict as a form of inter-role conflict arising because pressures from one role are incompatible with those from another role.

Grandey, Bryanne, and Ann (as cited in Sianturi \& Zulkarnain, 2013) identify that work-family conflict can use up a person's time and energy, cause feelings of being threatened, as well as bringing about negative behaviors at work. Emotional intelligence may be required to resolve these problems.

A study by Bukki (2014) showed that there is significant composite and relative contribution of emotional intelligence and work-family conflict on organizational citizenship behaviors among secondary school business teachers. Emotional intelligence is the most potent predictor. Based on these findings, Bukki's study recommended that organizations need to select teachers who have high emotional intelligence, because this may have a positive impact on the maintaining of their work performance. The Ministry of Education can organize intervention programmes, which would enable business teachers to balance work and family needs, so as to resolve any workfamily conflict, in order to encourage educators to perform better.

Emotional intelligence is defined by Feldmen (2011) as the basis for empathy for others, self-awareness, and social skills, which are useful for interaction with others, as well as abilities which can help to understand what other people feel, and how they express it. Salovy and Mayer (as cited in Bighami, Abdi, \& Aliakbar, 2013) define emotional intelligence as the ability of an individual to perceive accurately, appraise, and express emotion; the ability to access and generate feelings when thinking; the ability to understand emotion and emotional knowledge; and the ability to regulate emotions to promote emotional and intellectual growth.

Goleman (2015) divided emotional intelligence into five dimensions, namely recognizing the emotions of self, managing the emotions of self, motivating oneself, recognizing the emotions of others, and forming relationships with others. When individuals are not able to manage their emotions well, workfamily conflict can be greatly increased. Gao, Shi, Niu, and Wang (2012) found that Family to Work Interference (FWI) and Work to Family Interference (WFI) were negatively related to job satisfaction and that emotional intelligence weakened the effect of WFC on job satisfaction. High emotional intelligence helps employees to balance work-family conflict (WFC), so employees with high emotional intelligence may be able to prevent WFC, because they are able to recognize the extent to which work and family roles affect their emotions, and they have knowledge about how emotions should be managed. Thus, they have the ability to protect their job satisfaction from negative influences.

Mathur and Swami's (2015) study showed that working couples not only look out for their own career prospects but also nurture their children and contribute to their future prospects as well. The results of Mathur and Swami's research show that the correlation between conflicts which occur at work and in the household, and satisfaction in work and family life, affect one's overall life satisfaction. Satisfaction with one's self is one component of subjective wellbeing (Compton, 2005). As revealed by Diener and Scollon (as cited in Juniarly \& Hadjam, 2012), 
subjective wellbeing is a subjective evaluation of one's own life, which includes concepts such as life satisfaction, pleasant emotions, meaningful feelings, satisfaction in areas such as marriage and work, and low levels of unpleasant emotions.

Matthews, Wayne, and Ford (2014) tested predictive models of stress reactions and theoretical adaptation of the longitudinal relationship between dualrole conflict and subjective wellbeing. Matthews et al.'s research results showed that work-family conflict is related to low level subjective wellbeing, however, exposure to work-family conflict in the past contributes to higher subjective wellbeing over time - which is ostensibly contradictive but is in accordance with adaptation theories.

Argyle et al. (as cited in Juniarly \& Hadjam, 2012) describe six core variables to predict happiness and satisfaction with life. These are: positive self-esteem, a sense of perceived control, extroversion, optimism, positive social relationships, and a sense of meaning and purpose in life. In addition to these variables, Compton (2005) proposed another component of subjective wellbeing, that is, low self-reported neuroticism.

Given the above description, it may be said that there are two kinds of conflicts experienced by working women, that is, work interfering with family and family interfering with work, where women are required to manage their work, but on the other hand they feel guilty for not being able to spend more time with their families, which influences their wellbeing. Only high emotional intelligence can help employees to balance their work-family conflict, and prevent it from affecting both work and family, so they can reach subjective wellbeing.

This study aims to determine the contribution of emotional intelligence and subjective wellbeing to work-family conflict. The research hypothesis is divided into major and minor hypotheses. The major hypothesis is that there is a contribution from emotional intelligence and subjective wellbeing to workfamily conflict, while the minor hypothesis is that there is a contribution from emotional intelligence toward work-family conflict, and there is also a contribution from subjective wellbeing toward work-family conflict.

\section{Method}

\section{The Participants}

The research population was all female lecturers working at the University of Sriwijaya $(N=537)$. The criteria of the research participants were as follows:

a. permanent lecturer who works at the University of Sriwijaya.

b. have been married and have child(ren).

c. the child(ren) are aged from 1 month to 12 years old.

There are 380 lecturers who meet the criteria. Based on Isaac and Michael's (as cited in Sugiyono, 2014) table on a $5 \%$ level, the sample from these 380 people is 182 . As many as 52 participants participated during the pilot study of the instruments scales. The sampling technique used was incidental sampling.

\section{Data Collection}

Data were collected using psychological scales and interviews. The scales were constructed according to the Likert scale model, which measures attitudes by expressing agreement or disagreement with a particular subject, object or event (This Likert scale consists of four alternative answers, namely: very relevant, relevant, not relevant, very irrelevant. The scale consists of favorable and unfavorable answers to the attribute being measured. The nature of the answer determines the score to be given.

The scores on the favorable answers are given as follows: 4 (very relevant), 3 (relevant), 2 (not relevant), and 1 (very irrelevant); and vice versa for the unfavorable answers.

\section{Work-Family Conflict Scale}

The work-family conflict scale consists of two varieties of work-family conflict (Frone et al., 2005; Noor, 2004), namely, work interfering with family (using indicators from Boles et al. (as cited in Anafarta, 2011) and family interfering with work (using indicators from Frone et al., 2005).

\section{Emotional Intelligence Scale}

The emotional intelligence scale consists of five dimensions of emotional intelligence as defined by Goleman (2015), that is, recognizing one's own emotions, managing one's own emotions, motivating oneself, recognizing others' emotions and developing relationships with others.

\section{Subjective Wellbeing}

The subjective wellbeing scale used was modified from Juniarly and Hadjam (2012) with reference to the predictors of subjective wellbeing from Argyle, 
Myers, and Diener (as cited in Compton, 2005) namely, positive self-esteem, sense of perceived control, extroversion, optimism, positive social relationships, and a sense of meaning and purpose in life, and low selfreported neuroticism.

The interviews conducted in this study were unstructured, using short questions focusing on participants perceptions and the ways they responded to their roles as housewives and as lecturers. The questions included what problems or conflicts they experienced in their roles as housewives and lecturers, what negative impacts of work-family conflict affected their work and family lives, and what are the main reasons they still want to undertake double roles. The purpose of this interview is to screen potential participants and to provide supporting data for the initial survey of research, to strengthen the phenomenon of research in the field. The interview data were also used to discuss the research results. The interviews were conducted with eight lecturers who were married and had children; each interview lasting 30-60 minutes. The results of these interviews were used to describe the phenomena and to discuss the research results.

\section{Data Analysis Technique}

Statistical analysis techniques used in this study were reliability, normality and hypothesis tests; which were conducted using the SPSS version 16.00. Multiple linear regression analysis was used for the hypothesis testing.

\section{Results}

\section{Validity and Reliability}

Work-family Conflict scale. The validity coefficients of valid items ranged from $r_{i t}=.326$ to .736 . The reliability coefficient alpha $(\alpha)$ for this scale was .739 with items $N=40$. After being tested again with items $N=19$, the reliability coefficient alpha $(\alpha)$ became 898 .

Emotional Intelligence scale. The validity coefficient of valued items ranged from $r_{i t}=.323$ to .885 . The reliability coefficient alpha $(\alpha)$ for this scale was .876 with items $N=40$. After being tested again with items $N=22$, the reliability coefficient alpha $(\alpha)$ became 924 .

Subjective Wellbeing scale. The validity coefficient of valid items ranged from $r_{i t}=.303$ to .840 .
The reliability coefficient alpha $(\alpha)$ for this scale was .917 with items $N=70$. After being tested again with items $N=49$, the reliability t coefficient alpha $(\alpha)$ became .969 .

\section{Normality Test}

A normality test yields normal data, which is $K-S Z$ $=1.096, p=.181$ on the work-family conflict scale, $K-S Z=0.818, p=.515$ on the emotional intelligence scale, and $K-S Z=1.097, p=.180$ on the subjective wellbeing scale. The researchers conducted the normality test using multiple linear regression analysis (Figure 1), to see the distribution of normality after offending case deletion.

Normal P-P Standardized Residual Plots of Regression showed the partially data collected along the diagonal line, it being assumed that the residuals are normally distributed.

\section{Linearity Test}

The outliers-checking showed seven cases of outliers. To resolve this, the researcher conducted offending case deletion (Allen \& Bennet, 2012) by deleting cases with outlier scores. From 182 participants, researcher used only 175 participants. This is considered safe because outlier scores were not included in any particular classification in this study sample. After this data deletion, the next analysis was multiple regression analysis.

The other three assumptions (multicollinearity, linearity and homoscedasticity of residuals) were conducted by examining the results of multiple linear regression analyses. Linearity test results can be seen in Figure 2.

Work-family conflict variables showed the spread of scores does not form specific patterns which could indicate non-linearity, non-normality, and heteroscedasticity forms. It was concluded that the data form a normal, linear, distribution, so that multiple linear regression analysis can be performed.

\section{Description of Data}

In this study, the researcher described each research variable to get its Description of work-family conflict, emotional intelligence and subjective wellbeing scales are presented in the Table 1 .

\section{Hypothesis Testing}

Major hypothesis. The result of multiple linear 

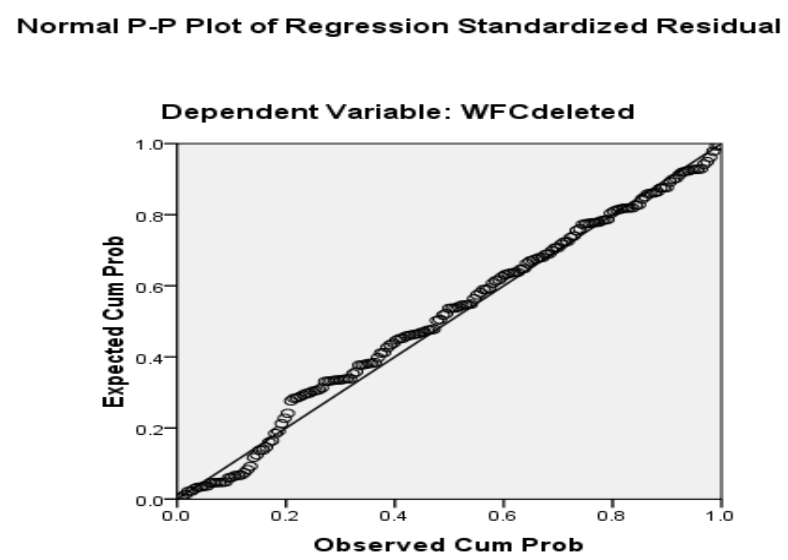

Figure 1. Standardized residual plots of regression.

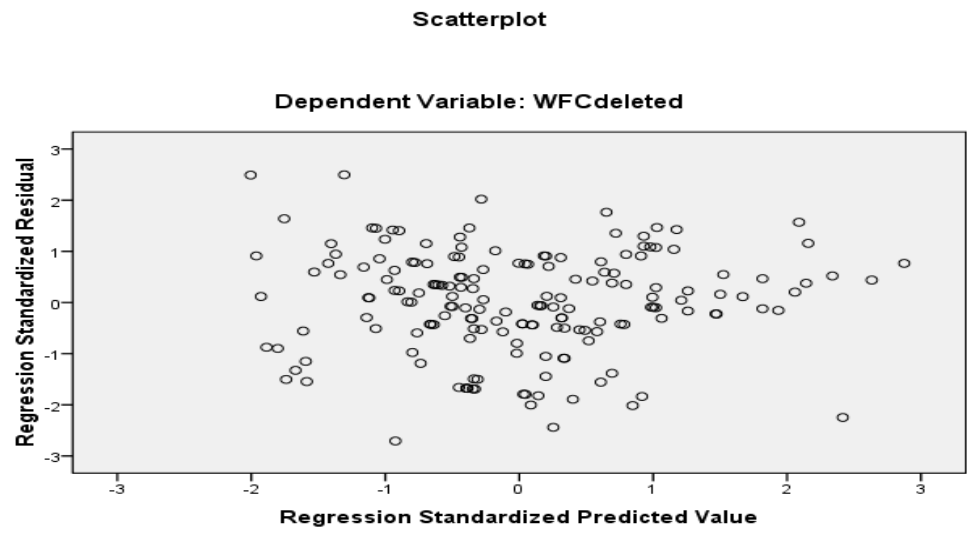

Figure 2. Linearity test results.

Table 1

Description of Research Data

\begin{tabular}{lcccccccc}
\hline \multirow{2}{*}{ Variable } & \multicolumn{3}{c}{ Hypothetical Data } & \multicolumn{4}{c}{ Empirical Data } \\
\cline { 2 - 8 } & Max & Min & Mean & SD & Max & Min & Mean & SD \\
\hline WFC & 76 & 19 & 47.5 & 9.5 & 49 & 23 & 38.09 & 5.259 \\
EI & 88 & 22 & 55 & 11 & 82 & 50 & 69.89 & 6.265 \\
SWB & 196 & 49 & 122.5 & 24.5 & 181 & 125 & 154.45 & 12.278 \\
\hline Note. & Min = Minimum Score; Max = Maximum Score; WFC = Work Family Conflict; EI & = Emotional Intelligence; SWB = Subjective WellBeing
\end{tabular}

regression analysis showed $R$-Square $=.070$, with $p$ $=.002(p<.05)$. Thus it can be concluded that there is a significant contribution of emotional intelligence and subjective wellbeing to work-family conflict among female lecturers at the University of Sriwijaya. Thus the null hypothesis is rejected. The contribution of emotional intelligence and subjective wellbeing to work-family conflict is $7 \%$, the remaining $93 \%$ being influenced by other factors.

Minor Hypothesis. The minor hypothesis testing are divided into two, which are emotional intelligence and work-family conflict minor hypothesis testing and subjective wellbeing and work-family conflict minor hypothesis testing.

Emotional Intelligence and Work-family Conflict. The result showed Beta $=-0.266$ with $p=.000(p$ $<.05)$. Thus it can be concluded that there is a significant contribution of emotional intelligence to workfamily conflict among female lecturers at the University of Sriwijaya. Thus the null hypothesis is rejected. The contribution of emotional intelligence to work-family conflict is $6.8 \%$.

Subjective Wellbeing and Work-Family Conflict. The result showed Beta $=0.046$ with $p=.539(p>.05)$. 
Thus it can be concluded that subjective wellbeing does not contribute to work-family conflict among female lecturers at the University of Sriwijaya. The null hypothesis is accepted.

\section{Additional Analysis}

Work-family Conflict. Additional analysis was performed on the types of work-family conflicts. The result showed that there was a significant difference in the scores for Work Interfering with Family type and Family Interferes with Work type which is Work Interfering with Family type is the one most felt by female lecturers at University of Sriwijaya, with $M$ $=24.537, S D=3.675$ conditions; $t(174)=88.334$, $p=.000$ and Family Interferes with Work type, which has $M=13.554, S D=2.694$ conditions; $t(174)=$ $66.547, p=.000$.

Emotional Intelligence. Additional analysis was performed on the aspects of emotional intelligence. The results showed that there was a significant difference in the scores for Emotional Intelligence aspects which is the motivation of oneself was the aspect most performed by female lecturers at the University of Sriwijaya, with the value of the $M=19.200, S D=$ 2.051 conditions; $t(174)=123.834, p=.000$. Identifying others' emotions was the second most often performed, with the value of the $M=18.863, S D=$ 2.211 conditions; $t(174)=112.852, p=.000$. However, on the emotional recognition aspect, the average female lecturer at the University of Sriwijaya has a low $M=6.00, S D=0.994$ conditions; $t(174)=$ $79.833, p=.000$, meaning that the average female lecturer at the University of Sriwijaya does not yet know her own emotions, but can motivate herself, and recognize the emotions of others.

Subjective Wellbeing. Additional analysis was performed on the subjective wellbeing predictors. The result showed that there was a significant difference in the scores for Subjective Wellbeing predictors which is most female lecturers at the University of Sriwijaya have positive self-esteem, with the value of the $M=29.331, S D=2.596$ conditions; $t(174)=$ $149.458, p=.000$, followed by attitude of optimism, with the value of the $M=26.463, S D=2.941$, conditions; $t(174)=119.011, p=.000$ and sense of perceived control, with the value of the $M=26.046, S D=$ 2.930 conditions; $t(174)=117.600, p=.000$. Optimistic attitudes make female lecturers at the University of Sriwijaya have low neuroticism, with the value of the $M=17.20, S D=1.622$ conditions; $t(174)=140.246, p=.000$.

\section{Discussion}

The results of multiple linear regression statistical analysis on emotional intelligence, subjective wellbeing, and work-family conflict variables showed that there is a significant contribution from emotional intelligence and subjective wellbeing to work-family conflict, among female lecturers at the University of Sriwijaya.

\section{Emotional Intelligence and Work-family Conflict}

The results of multiple linear regression analysis for the minor hypothesis showed that there is a significant contribution from emotional intelligence to work-family conflict among female lecturers at the University of Sriwijaya. The results of this study support the results of Carmeli's (2003) research which showed that someone with high emotional intelligence can be more effective in controlling work-family conflict. Dasgupta's (2011) research also showed that emotional intelligence has a negative correlation with work-family conflict. The higher one's emotional intelligence, the less they experience work-family conflict. According to Goleman (2015), emotional intelligence is the ability to motivate oneself and survive frustration, control impulses and not to be taken over by immediate gratification, to regulate moods and keep stress from crippling the ability to think, and to empathize. High emotional intelligence makes a person more capable of overcoming various problems, especially those requiring strong emotional control. Bukki (2014) cite Goleman's assertion that how one controls and manages one's emotions will determine how workfamily conflict occurs.

Research by Lenaghan, Buda, and Eisner (2007) reinforces the results of this research, in which it is shown that emotional intelligence acts as a protective variable against the negative impact of workfamily conflict on one's own wellbeing.

\section{Subjective Wellbeing and Work-Family Conflict}

The other results of multiple linear regression analysis showed that there is no contribution from subjective wellbeing to work-family conflict, amongst female lecturers at the University of Sriwijaya.

Research from Rani and Darolia (2011) also supports the results of this study, where it is known that emotional intelligence significantly mediated the 
impact of work-family interference on wellbeing. The findings of this study clearly suggest the mediating role of emotional intelligence in reducing the negative impact of work-family interference on the wellbeing of working Indian women. People who have high emotional intelligence experience lesser distress and maintain better wellbeing. Therefore, it seems plausible that strategies enhancing the understanding and management of emotions may play great role in handling distress at both levels, that is at work and in the family.

In other words, from the results of the research by Lenaghan et al. (2007) as well as Rani and Darolia (2011), it can be concluded that when there are workfamily conflicts, emotional intelligence will help to reduce it, and, subsequently, female lecturers should reach subjective wellbeing. Thus the authors conclude that the absence of subjective well-being towards work family conflict occurs because the two of variables are not directly related but there is mediation of emotional intelligence variable in there. It is meant that the mediation of emotional intelligence can reduce work family conflict experienced, and subsequently, female lecturers can reach subjective wellbeing.

\section{Additional Analysis}

The results of the categorization of emotional intelligence, subjective wellbeing and work-family conflict show that female lecturers at the University of Sriwijaya have high emotional intelligence and subjective wellbeing, and medium to low work-family conflict. The study found that female lecturers with high emotional intelligence mostly use the self-motivating aspect. As Goleman (2015) pointed out, selfmotivation is needed, so that individuals can better enjoy each challenge and be more productive and effective in everything they undertake. Working as lecturers demands that women to be more professional and active in performing the Tridharma of Higher Education. As professionals, lecturers need skills, or skills meeting certain qualities or standards, and require professional education. These demands ultimately make female lecturers need to enjoy every challenge and be more productive and effective in everything they do (Goleman).

In addition to the self-motivating aspects, the aspect of recognition of others' emotions is also quite high amongst female lecturers at the University of Sriwijaya. According to Goleman (2015), recognizing the emotions of others is related to the ability to mingle, the ability to capture hidden signals indicating what is needed or desired by others. With this ability, female lecturers can recognize hidden signals indicating what is needed or desired by their students.

Female lecturers at the University of Sriwijaya have low ability to manage emotions and to recognize their own emotions. Cleary's research (Hennessy, 2005) indicated that special skills are needed for women to balance responsibilities at work and at home, so that these responsibilities do not to cause more serious problems. One of the skills needed to balance the conflict is the ability to recognize and manage emotions. The abilities to recognize, manage, and express emotions are aspects of emotional intelligence.

In terms of subjective wellbeing, female lecturers at the University of Sriwijaya have positive selfesteem. Campbell (as cited in Juniarly \& Hadjam, 2012) found that self-esteem is the most important predictor of subjective wellbeing. High self-esteem gives a person several advantages, including an understanding of the meaning and value of life. From the interviews conducted, it is known that working as lecturers leads to most female lecturers at the University of Sriwijaya feeling proud of their work. Higher education has enabled them to feel confident as lecturers. As revealed by Sahin, Barut, and Ersanli (2013), there is a significant variance in adolescents' self-esteem, based on their parents' educational level. The findings suggest that the level of parental education positively affects the self-esteem of Turkish adolescents. Raymore, Godbey, and Crawford (as cited in Sahin, Barut, \& Ersanli, 2013) explained that adolescents whose parents have high levels of education have significantly higher self-esteem than adolescents whose parents have low levels of education.

High emotional intelligence among female lecturers at the University of Sriwijaya leads their neuroticism being low. With a low level of neuroticism, they can focus more on their work, and not worry too much about their responsibilities as mothers and wives. It is because they can manage themselves to balance the roles of lecturer, mother, and wife. This is in accord with Gao, Shi, Niu, \& Wang (2012) research, which showed that high emotional intelligence helps employees balance work-family conflict, so employees with high emotional intelligence may be better able to prevent WFC. Their high emotional intelligence enables them to recognize the extent to which work and family play a role in their emotions, and to have insights into how their emotions should be managed. Thus, they have the ability to protect job satisfaction from negative influences. 
The value of $R$-square indicates that $93 \%$ of workfamily conflict is influenced by other factors, not examined in this study. In other words, it may be concluded that the role of emotional intelligence and subjective wellbeing regarding work-family conflict is not too significant in affecting female lecturers at the University of Sriwijaya. This low contribution may happen because of many other factors which influence work-family conflicts. As revealed by Biggart, Corr, O'Brien, \& Cooper (2010), factors influencing workfamily conflict include organizational and family characteristics. Appolo and Cahyadi (2012) stated that there are several factors influencing work-family conflict. First are internal factors, namely issues arising in private; Second are external factors arising outside, such as husband support, child attendance, and employment issues. Third, are relational factors, with husbands and children, and motivation, namely financial needs and self-actualization.

Following these explanations, one factor which influences work-family conflict, but which was not examined in this study, is self-actualisation (Appolo $\&$ Cahyadi, 2012). From the interviews with several female lecturers, it is known that they are proud to be lecturers. They recognize that, by working as lecturers, they can actualize themselves, share knowledge with students, conduct research and community service, so their lives are not only about being housewives and working around the house, but they can also establish social relationships with others, and develop themselves.

Another thing influencing work-family conflict, but which was not investigated in this research, is husband support (Appolo \& Cahyadi, 2012). Based on the results of additional interviews with several female lecturers, it is known that the main cause of the work-family conflict they experienced is the lack of their husbands' support for their work. Some female lecturers stated that sometimes husbands ask them not to bring their work home after a day at the university, whilst the demands of work sometimes make them have to take their work home, as time on campus is not sufficient to complete their tasks. If not immediately resolved, this inability can disadvantage their students. For example, a female lecturer may teach all day on campus for five working days, whilst the location of the campus is outside the city. It may take 23 hours to drive to and from the campus, making some female lecturers physically exhausted, so they do not have time to check students' theses or assignments on campus. In the end, the theses or students' assignments are taken home to be marked. These conditions some- times make the husbands angry, or eventually lead to the husbands ignoring their wives at home, because they do not agree with the wives taking their work home. In the end, this adds to the work-family conflict experienced.

The husband's complaints over taking work home is consistent with the results of additional analysis showing that Work Interfering with Family is felt by most female lecturers at the University of Sriwijaya. According to Frone, Barling, and Kelloway (2005), work interfering with family occurs when work-related activities interfere with home responsibilities, for example, with the wife bringing home work at the expense of family time.

\section{Limitations}

Some of the statements coming from the psychological scales in this study were not measured correctly, so many items were invalid. This affects the distribution of favorable and unfavorable items. The emotional intelligence scale left only two items in the aspect of recognizing the emotions of the self, and no favorable items were left on the predictor of low neuroticism in subjective wellbeing. In addition, there is a tendency for some participants to answer carelessly, so that seven outlier cases were found in the research data. Because of this, their data were removed to prevent it from affecting others' data.

\section{Conclusion and Suggestions}

Emotional intelligence has a contribution to make in reducing work-family conflict among female lecturers at the University of Sriwijaya. High emotional intelligence and subjective well-being may contribute to lower work-family conflict. Female lecturers who have high emotional intelligence may be better able to prevent work-family conflict owing to emotional intelligence. In addition, they are able to recognize the extent to which their role (work and family) can influence their emotions, and to have an insight into how their emotions should be managed. Thus, they have the ability to protect job satisfaction from negative influences, and ultimately to achieve subjective wellbeing.

To minimize work-family conflict, participants should strive to continue to improve their ability to manage their emotions, and they should know which emotions need to be improved. Besides that, they need to maintain their ability to motivate themselves, to know the emotions of others and to build relation- 
ships with others. In addition, they should be open/ honest with their husbands about the consequences/ effects of working as female lecturers. If they can be open/honest with their husbands, it is expected that their husbands will understand the existing conditions and seek a win-win solution, where the wife can still carry out her responsibilities as a wife and mother, and as well as as a lecturer.

For the institution, one of the possible ways to minimize work-family conflict and to reach subjective wellbeing among female lecturers at the University of Sriwijaya is by providing an emotional intelligence training program.

Researchers who want to raise the theme of workfamily conflict, especially regarding female lecturers, may wish to examine the support of husbands, or organizational characteristics.

\section{References}

Allen, P., \& Bennett, K. (2012). Statistics: A practical guide version 20. Australia: National Libarary of Australia Cataloging in Publication Data.

Anafarta, N. (2011). The relationship between workfamily conflict and job satisfaction: A structural equation modeling (SEM) approach. International Journal of Business and Management, 6(4), 168177.

Apollo, \& Cahyadi. (2012). Konflik peran ganda perempuan menikah yang bekerja ditinjau dari dukungan sosial keluarga dan penyesuaian diri. Widya Warta, 2, 254-271.

Azwar, S. (2014). Penyusunan skala psikologi. Yogyakarta: Pustaka Pelajar.

Baah, K. D. (2015). Work-family conflict, demographic characteristics and job satisfaction among Ghanaian corporate leaders. International Journal of Business, 20(4), 291-307.

Bighami, M. K., Abdi, F., \& Aliakbar, M. S. (2013). The effect of emotional intelligence on work-family conflict between employees in manufacturing environment using structural equation modeling. Shiraz Journal of System Management, 1(2), 67-79.

Biggart, L., Corr, P., O’Brien, M., \& Cooper, N. (2010). Trait emotional intelligence and workfamily conflict in fathers. Personality and Individual Differences, 48, 911-916.

Bukki, A. O. (2014). Influence of emotional intelligence and work-family conflict on organizational citizenship behaviour of secondary school business subjects' teachers in Ogun State. Journal of Education and Human Development, 3(3), 301-308.

Carmeli, A. (2003). The relationship between emotional intelligence and work attitudes, behavior and outcomes: an examination among senior managers. Journal of Managerial Psychology, 18(8), 788-813.

Compton,W. C. (2005). An introduction to positive psychology. Stamford, Connecticut: Thompson Learning, Inc.

Dasgupta, M. (2011). Emotional intelligence emerging as a significant tool for female information technology professionals in managing role conflict and enhancing quality of work-life and happiness. Asian Journal of Management Research, 1(2), 558-565.

Erkmen, T., \& Esen, E. (2014). Work-family, familywork conflict and turnover intentions among the representatives of insurance agencies. Journal of Business, Economics, and Finance, 3(3), 302-312.

Feldmen, R. S. (2011). Understanding psychology (10th ed). New York: McGraw-Hill Companies, Inc.

Frone, M. R., Barling, J., \& Kelloway, E. K. (2005). Handbook of work stress. New Delhi: Sage Publications. https://doi.org/10.4135/9781412975995

Gao, Y., Shi, J., Niu, Q., \& Wang, L. (2012). Workfamily conflict and job satisfaction: Emotional intelligence as a moderator. Stress Health, 29(3), 222-228. https://doi.org/10.1002/smi.2451

Goleman, D. (2015). Emotional intelligence: Mengapa EQ lebih penting daripada IQ (Hermaya, Pengalih bhs). Jakarta: Gramedia Pustaka Utama.

Hennessy, K. D. (2005). Work-family conflict selfefficacy: A scale validation study (Unpublished master's thesis). University of Maryland, United States.

Juniarly, A., \& Hadjam, M. N. R. (2012). Peran koping religius dan kesejahteraan subjektif terhadap stres pada bintara polisi di Polres Kebumen. Psikologika, 17(1), 5-16.

Lenaghan, J. A., Buda, R., \& Eisner, A. B. (2007). An examination of the role of emotional intelligence in work and family conflict. Journal of Managerial Issues, 19(1), 76-94.

Mathur, R., \& Swami, N. (2015). Work-family conflict: Coping strategies to optimize wellbeing in working couples. A Peer-Based Monthly Research Journal, 1(9), 18-24.

Matthews, R. A., Wayne, J. H., \& Ford, M. T. (2014). A work-family conflict/subjective wellbeing process model: A test of competing theories of longitudinal effects. Journal of Applied Psychology, 99(6), 1173-1187. https://doi.org/10.1037/a0036674

Noor, N. M. (2004). Work-family conflict, work-and 
family-role salience, and women's wellbeing. The Journal of Social Psychology, 144(4), 389-405.

Rahayu, A. W. (2015). Perempuan dan belenggu peran kultural (online). Retrieved from https://www. jurnalperempuan.org/blog-muda1/women-and-cl utch-percultural

Rani, A., \& Darolia, C. R. (2011). Work-family interference and well being in Indian women: Mediating role of emotional intelligence. Journal of the Indian Academy of Applied Psychology, 37, 25-33.

Sahin, E., Barut, Y., \& Ersanli, E. (2013). Parental education level positively affects self-esteem of
Turkish adolescents. Journal of Education and Practice, 4(20), 87-97.

Sianturi, M. M., \& Zulkarnain. (2013). Analisis work family conflict terhadap kesejahteraan psikologis pekerja. Jurnal Sains dan Praktik Psikologi, 1(3), 207-215.

Sugiyono. (2014). Quantitative and qualitative research methods and $R \& D$. Bandung: Alfabeta

Undang-Undang Republik Indonesia Nomor 14 tahun 2005, Pasal 1 (1) tentang ketentuan umum guru dan dosen. (2017). Retrieved from luk.staff.ugm. ac.id/atur/UU14-2005GuruDosen.pdf. 